\title{
The Working Motivation of Doctors in the Era of National Health Insurance in Ngesrep Primary Health Care (PHC) 2015
}

\section{Septiana Maharanti1, Sudiro Soedarso², Putri Asmita², and Dewi Susanna ${ }^{3}$ \\ ${ }^{1}$ Administration Health Policy Department, Public Health Faculty, Universitas Indonesia ${ }^{2}$ Administration Health Policy Department, Public Health Faculty, Diponegoro University ${ }^{3}$ Environmental Health Department, Public Health Faculty, Universitas Indonesia}

\section{Abstract}

Doctors in Primary Health Care (PHC) Ngesrep were found to be disappointed with their workload that is related to the implementation of Badan Penyelenggara Jaminan Sosial (BPJS). Doctors felt burdened by the increase in the total amount of BPJS participants. Average number of visits by Health Insurance participants in 2013 was 199 patients every month. Meanwhile, in 2014, the number of BPJS patients

Corresponding Author: Dewi Susanna dsusanna@ui.ac.id Septiana Maharant maharanti_septiana@ yahoo.com

Received: 21 January 2018 Accepted: 8 April 2018 Published: 17 May 2018

Publishing services provided by Knowledge

(c) Septiana Maharanti et al. This article is distributed under the terms of the Attribution License, which permits unrestricted use and redistribution provided that the original author and source are credited.

Selection and Peer-review under the responsibility of the 2nd International Meeting of Public Health 2016 Conference Committee.

\section{G OPEN ACCESS} reached 668. Doctors' work performance became less optimal since they worked without motivation, shown by the high (36\%) referral ratio. Ngesrep PHC referred the patients with diseases that could be treated by Health Care Provider Level I, such as Diabetes Mellitus, Vertigo, Bronchitis and Presbyopia. The goal of research was to identify factors that are related to the work motivation of the doctors in Ngesrep PHC. This research used a qualitative method with a descriptive approach. The data collection was undertaken using an in-depth interview. This research found that there is additional administrative work. There are no training opportunities; supervision is undertaken incidentally through personal interviews. The physical and psychological working conditions not conducive enough. The facilities are not adequate to support doctors' work. The incentives do not yet conform to doctors' workloads. It is advised that the head of PHC should cooperate with BPJS in improving work performance, providing training opportunities and incentivizing the doctors.

Keywords: work motivation, primary health care doctors, health insurance.

\section{INRODUCTION}

Working on Social Security Agency for Health or "Badan Penyelenggara Jaminan Sosial" (BPJS), doctors are burdened with many tasks. They have to examine the patient, record the diagnosis, administer medications, and take the decision whether to refer the patient. In organizing the social health security, BPJS has rules and commitments. 
Modification to policy and changes in political situation rapidly affect doctors' work in PHC.

Unclear regulations lead to doctors feeling confused about their job. Such as, the authority of doctors conducted medical practice according to quality and cost control. According to President Regulation number 12 Year 2013 on Health Insurance, participants must fulfill certain quality aspects. The realization of this will depend on medical practice in Indonesia and on how BPJS organize the formulation of policies related to medical practice in PHC.

In accordance with Herzberg's theory [6] about organizational factors in motivation, doctors need to build motivation and require good organization. Herzberg stated that the motivational factors could be divided into two categories: satisfaction and no satisfaction. Motivational factors directly relate to the work done by doctors, such as achievement, recognition of their work, development, and responsibility. Hygiene factors refer to the working environment, such as policies, incentives, labor relations, and workplace conditions [12].

BPJS has determined that the referral ratio from primary health care to secondary health care is not more than $15 \%$. The referral ratio in Ngesrep PHC was more than $15 \%$. In this case, doctors are required to work effectively and efficiently. In order to be effective the result coverage must match the target. In fact, doctors were not working in accordance with BPJS targets, and were still far away from expectations. Meanwhile, efficiency involves using existing resources for optimum achievement; a doctor could treating hundreds of patients in a day in accordance with the service hours in PHC. However, with condition more efficient can lead to neglected [3]. Researchers are interested infurther exploring the work motivation of doctors in the era of BPJS at Ngesrep PHC and identifying which factors have a great impact on productivity.

\section{METHODS}

The type of research employed was qualitative and descriptive. The subjects were two people as key informants, a general doctor and a dentist. For informant triangulation was the Head of PHC. The collection of data was achieved by observing related documents and carrying out in-depth interviews about work motivation. Then, the researchers made inferences about the data to obtain a general and complete overview of the subject in accordance with the purpose of the research. 


\section{RESULTS}

\subsection{Achievement}

The results showed that doctors' work is not rated by BPJS. Since BPJS did not require indicators to be achieved, the doctors did not orient their work toward these. However, doctors claimed that an appraisal of their achievement was much needed, in order for them to understand their accomplishments and to evaluate of their work performance. The acknowledgment of achievements would encourage doctors' work motivation.

\subsection{Occupation}

The results showed that doctors' workload was not heavy because the doctors worked under the condition of being in the patient room. The duration of the working day is six hours, from 8 AM until 2 PM. The time is ideal for someone to be productive in their work. The doctors performed the tasks of serving patients according to SOP (Standard Operating Procedure). Patients who already sign up were called by their corresponding serial number. The doctor listened to the patient's complaint. Then the doctor examined the patient and recorded the diagnosis. After that, the doctor took the decision to refer the patient's case or to prescribe medication.

The research revealed that the doctor's work did not only involve serving patients, but that they were also burdened with administrative tasks. This is known as responsible procurement. On the other hand, additional tasks related to their profession included being coordinator of School Health Unit and Basic Emergency Neonatal Obstetrics Services or Pelayanan Obstetri Neonatal Emergensi Dasar (PONED).

\subsection{Development}

The results showed that the chance or opportunity for development does not exist. Doctors have not received the training appointed by BPJS, such as Diabetes Mellitus Type 2 Handling Program and Hypertension Management Program. Training should be given by BPJS to support doctors' work; however, doctors have the will to improve themselves by undertaking training at a personal cost. 


\subsection{Supervision}

Doctors stated that it was vital that supervision be implemented, because with this would enable their duties and tasks to be evaluated. Monitoring by the Head of Ngesrep PHC was restricted to an incidental interview when there is a complaint, such as patients complaining about the doctors' quality of service. The Head of Ngesrep PHC provided advice and warnings to doctors related to the serving procedures that have been agreed. Input from doctors about supervision can be undertaken regularly and scheduled. Supervision should not only be carried out when an error occurs, but should be established regularly. Supervision by the leader is needed by subordinates, because with this can improve the performance of subordinates in their duties.

\subsection{Working Conditions and Environment}

The results showed that the availability of infrastructure to support doctors' work, such as stethoscopes, sphygmomanometers and dental units, was quite adequate. However, the availability of drugs was not yet complete due to delays from Health Department and drugs needed by patients not being listed in DPHO. Meanwhile, the psychological environment was less conducive because there were differences of opinion about the ratio BPJS capitation for health resources at Ngesrep PHC. Additionally, the physical environment was not good enough. This was due to the building being old and the ceiling beginning to perforate. The doctors were separated by partitions to provide privacy to the patients. The impact of thiswasthat doctors found it difficult to move because the space was too narrow.

\subsection{Incentive}

It was found that salary or capitation incentives were paid on time. However, doctors claimed that incentives of capitation did not meet with the workload. There is PHC with a little bit patients and a light workload get more acquisition capitation because calculation capitation given by BPS accordance to caput or head listed on health care providers. Doctors hoped there would be an increase in the acquisition of services from capitation per month.

\section{DISCUSSION}




\subsection{Achievement}

Herzberg (1966) assumed that there is a zero midpoint between dissatisfaction and satisfaction. It is clear that if a member of an organization who is receiving good supervision, sufficient income and great working conditions, but is dealing with lack of achievement, the motivator factor will be in the midpoint. That person will either experience dissatisfaction (because of well hygiene factor) or satisfaction [12]. If this motivator factor is fulfilled then it will have a positive impact on working satisfaction and the person's working motivation will increase. This case is strengthened by research undertaken by Umi Kulsum which found that working achievement has a simultaneous positive effect on working motivation, which means that if working achievement increases so does working motivation [7].

\subsection{Occupation}

Herzberg (1966) expressed that if a person intrinsically loves his/her job there is a possibility he/she will use his/her creativity and be more innovative, working with high level of autonomy without being supervised. Therefore, not only are a good income and great working conditions required to motivate a doctor, but an enriched job, which is given to each person in order to increase the achievement and promotion of his/her career, is also needed. A motivator factor can increase job satisfaction, but if this factor is not fulfilled job dissatisfaction will not be affected. In principle, fulfilling the motivator factor is important to encourage motivation and increasing the level of performance $[5]$.

\subsection{Development}

Working motivation is directly connected to the opportunities to improve and develop one's job. If a person felt that what they have done at their job could help them to learn new things and encourage them to improve, then their motivation will increase [11].

There are two job factors which always affect employee performance; one of these is the motivator factor, resulting from experience and the job itself, which creates a positive attitude to their job [10]. This condition could be compared to self-improvement. Therefore, improving individual potential is one factor that acts as background motivation for the satisfaction and dissatisfaction of the job. This 
case corresponds with research undertaken by Ahmad (2010) that showed that the improvement aspect has a greater effect on job motivation than other hygiene factors.

\subsection{Supervision}

According to research conducted by Faridah (2010), the supervision performed by the head of PHC, who did not provide any guidance and coaching, was such a disappointment for employees because supervision activities, which were carried out unsystematically, would not motivate employees to improve their performance and the implementation of work would not improve either.

According to Herzberg (1966), the hygiene factor did not encourage a person's interest to perform well. When the hygiene factor was considered as dissatisfaction in the aspect of supervision, this might be unpleasant and could potentially become a source of discontent [2]. If the hygiene factor was fulfilled, it would not give a positive value to the satisfaction of one's work, but when the hygiene factor was violated or not complied to, it would trigger job dissatisfaction and could result in demotivation.

\subsection{Working Conditions and Environment}

In accordance with research conducted by Lubis (2008), it was shown that working conditions affected working motivation for doctors; for example, performance could be affected by working conditions that caused discomfort when examining patients. Therefore, improvements on the physical environment, facilities, and infrastructure are needed by doctors so they become more motivated when undertaking their duties and this can result in an improved performance [8]. As proposed by Frederick Herzberg (1966), there are two working factors that always affect the performance of employees. One of these is working conditions, which is included in the hygiene factors. A hygiene factor is an external factor related to the productivity of a job. Furthermore, Herzberg explained that the two factors, namely motivating and hygiene factors, are interrelated. If the motivating factor is already good, but the hygiene factor is not very supportive- for instance, if the infrastructure are not available, such as the unavailability of drugs and consumable dental fillings - then the work would certainly not be optimal [10]. 


\subsection{Incentive}

The capitation fund was obtained by Ngesrep PHC with 9,271 participants BPJS in which capitation rates of six thousand Rupiah was approximately 55 million Rupiah per month. Acquisition of capitation for doctors per month was 1.7 million of the total funds. However, the new policy was settled on BPJS Regulation No. 2 in 2015 on The Norm of Capitation Magnitude Determination Based on Fulfillment of Services Commitment in the First Level of Health Facility, in which capitation PHC was settled at three thousand to six thousand Rupiah. Hence, Ngesrep PHC encountered the decline of the capitalization. Capitation funds obtained per month became 42 million. This has an impact on the services revenue of doctors due to the decreasing of capitation.

Based on research conducted by Noer in 2005 there was injustice regarding compensation in the form of capitation. The factor that affected the dissatisfaction of doctors from the hygiene factors was the salary variable. The participants requested their rights in full. Those rights included expensive drugs, specialist referral, medical checkups/x-ray pictures, and medical action, among others. Meanwhile, the capitation fees equaled only the parking lot fees [9]. Herzberg (1966) simply formulated his theory as +1 and -1 . If motivation is the result of hygiene factors and motivating factors, then every time hygiene factors are violated, it will give the value of -1 , and when the motivating factor is fulfilled, it will give the value of +1 . The best strategy is not to violate the hygiene factors and to fulfill the motivating factor.

\section{CONCLUSIONS}

There was additional administrative work. There were no training opportunities; supervision was undertaken incidentally through personal interviews. Physical and psychological working conditions was not conducive enough, and the facilities were not adequate to support the doctors' work. The incentives did not yet meet with the doctors' workloads. It is advised that the Head of PHC should understand that motivation factors can either support or obstruct the doctors' work motivation and that the Head should cooperate with BPJS in attempting to improve work performance, training opportunities and incentivization for the doctors. 


\section{ACKNOWLEDGMENTS}

The authors would like to thank to all the team who have the time and ability to help the writers complete this research.

\section{References}

[1] Ahmad. 2010. Pengaruh Motivasi dan Beban Kerja terhadap Kinerja Karyawan di Rumah Sakit Nur Hidayah Bantul. Thesis, Yogyakarta: FKM Univ Ahmad Dahlan.

[2] Cushway, and Lodge. 2002. Organizational Behaviour and Design. Jakarta: PT Elex Media Komputindo,

[3] Danakusuma. 1996. Pengantar Kesehatan Masyarakat dan Kedokteran Komunitas. Jakarta: IDI.

[4] Faridah. 2010. Analisis Faktor-Faktor yang Berpengaruh terhadap Motivasi Kerja Petugas Pelaksana Manajemen Terpadu Balita Sakit di Puskesmas. Thesis, Surabaya: STIKES Surabaya.

[5] Gibson, Donnelly, and Ivancevich. 1996. Organisasi: Perilaku, Struktur, Proses. Jakarta: Erlangga.

[6] Herzberg, F. (1966). Work and the nature of man. Cleveland: World Publishing Company.

[7] Kulsum, Umi. 2008. "Pengaruh Prestasi Kerja terhadap Motivasi Karyawan bagian Produksi PT. Pesona Remaja Malang." FE UIN MALANG.Accessed May 5, 2015. lib.iun-malang.ac.id/files/thesis/fullchapter/03220038.pdf.

[8] Lubis. 2008. Pengaruh Karakteristik Individu dan Motivasi Ekstrinsik terhadap Kinerja Dokter Dalam Kelengkapan Pengisian Rekam Medis Pasien Rawat Inap di RS PT Perkebunan Nusantara IV. thesis, Sumatera: Universitas Sumatera Utara.

[9] Noer. 2005. Faktor-Faktor yang Mempengaruhi Kepuasan Kerja dan Motivasi Dokter PT ASKES dalam Memberikan Pelayanan Kesehatan kepada Peserta PT ASKES Kota Malang, Madiun dan Kediri. thesis, Yogyakarta: Univ Gadjah Mada.

[10] Sukoco, Badri Munir. 2007. Manajemen Administrasi Perkantoran Modern. Surabaya: Erlangga.

[11] Susilo. 1997. Manajemen Sumberdaya Manusia. Jogjakarta: BPFE.

[12] Winardi. 2001. Motivasi dan pemotivasian dalam manajemen. Jakarta: PT Raja Grafindo Persada. 